\title{
Control of cytokine production by human Fc gamma receptors: implications for pathogen defense and autoimmunity
}

\author{
Lisa T. C. Vogelpoel ${ }^{1}$, Dominique L. P. Baeten ${ }^{2}$, Esther C. de Jong ${ }^{1}$ and Jeroen den Dunnen ${ }^{*}$ \\ Department of Cell Biology and Histology, Academic Medical Center, University of Amsterdam, Amsterdam, Netherlands \\ ${ }^{2}$ Department of Clinical Immunology and Rheumatology, Academic Medical Center, University of Amsterdam, Amsterdam, Netherlands
}

Edited by:

Pietro Ghezzi, Brighton and Sussex Medical School, UK

\section{Reviewed by:}

Britta Christina Urban, Liverpool School of Tropical Medicine, UK Charles Dinarello, University of Colorado Health Sciences Center, USA

\section{*Correspondence:}

Jeroen den Dunnen, Department of Cell Biology and Histology, Academic Medical Center, University of Amsterdam, Meibergdreef 15, Amsterdam AZ 1105, Netherlands e-mail: j.dendunnen@amc.nl
Control of cytokine production by immune cells is pivotal for counteracting infections via orchestration of local and systemic inflammation. Although their contribution has long been underexposed, it has recently become clear that human Fc gamma receptors (FcyRs), which are receptors for the Fc region of immunoglobulin $\mathrm{G}(\mathrm{lgG})$ antibodies, play a critical role in this process by controlling tissue- and pathogen-specific cytokine production. Whereas individual stimulation of Fc $\gamma R$ s does not evoke cytokine production, Fc $\gamma$ Rs celltype specifically interact with various other receptors for selective amplification or inhibition of particular cytokines, thereby tailoring cytokine responses to the immunological context. The physiological function of FcyR-mediated control of cytokine production is to counteract infections with various classes of pathogens. Upon IgG opsonization, pathogens are simultaneously recognized by Fc $\gamma$ Rs as well as by various pathogen-sensing receptors, leading to the induction of pathogen class-specific immune responses. However, when erroneously activated, the same mechanism also contributes to the development of autoimmune diseases such as rheumatoid arthritis and systemic lupus erythematosus. In this review, we discuss control of cytokine production as a novel function of Fc $\gamma$ Rs in human innate immune cells in the context of homeostasis, infection, and autoimmunity and address the possibilities for future therapeutic exploitation.

Keywords: antibacterial response, cross-talk, dendritic cells, Fc $\gamma$ Rlla, macrophages, rheumatoid arthritis, systemic lupus erythematosus, TNF $\alpha$

\section{INTRODUCTION}

Control of cytokine production is pivotal for controlling local and systemic inflammation and is required for shaping both innate and adaptive immune responses. Innate immune cells produce cytokines upon detection of pathogens or endogenous danger signals via activation of different families of receptors, which collectively are referred to as pattern recognition receptors (PRRs). The most well-known examples of PRRs are the families of tolllike receptors (TLRs), C-type lectin receptors, NOD-like receptors, and RIG-I-like receptors (1). However, the list of families of receptors that can induce or modulate cytokine production is still continuously expanding.

In the last 10 years, it has become apparent that also the family of $\mathrm{Fc}$ gamma receptors $(\mathrm{Fc} \gamma \mathrm{Rs})$, which are receptors for the

\footnotetext{
Abbreviations: ACPA, anti-citrullinated protein antibodies; ADCC, antibodydependent cellular cytotoxicity; CRP, C-reactive protein; DAMP, damage-associated molecular pattern; DC, dendritic cell; Fc $\gamma \mathrm{R}$, Fc gamma receptor; IgG, immunoglobulin G; ITAM, immunoreceptor tyrosine-based activation motif; ITAMi, inhibitory immunoreceptor tyrosine-based activation motif; ITIM, immunoreceptor tyrosinebased inhibitory motif; IVIG, intravenous immunoglobulin; PAMP, pathogenassociated molecular pattern; pDC, plasmacytoid dendritic cell; PRR, pattern recognition receptor; RA, rheumatoid arthritis; $\mathrm{SH}(\mathrm{I}) \mathrm{P}-1$, Src homology 2 domaincontaining (inositol) phosphatase-1; SLE, systemic lupus erythematosus; SNP, single nucleotide polymorphism; SSc, systemic sclerosis; Syk, spleen tyrosine kinase; TLR, toll-like receptor.
}

Fc region of immunoglobulin $\mathrm{G}(\mathrm{IgG})$ (2), plays a major role in orchestrating cytokine production. Fc $\gamma$ Rs have long been known to mediate a large variety of functions, such as antigen or pathogen uptake, degranulation, antigen presentation, and antibody-dependent cellular cytotoxicity (ADCC) [reviewed by Nimmerjahn and Ravetch (3) and Guilliams et al. (4)]. In contrast, their function in orchestrating inflammation by controlling the production of cytokines has long been underexposed. When evaluating recent findings, it appears that Fc $\gamma \mathrm{R}$-mediated control of cytokine production is physiologically important to tailor immune responses to efficiently counteract pathogens. However, when activated undesirably, the same mechanism of Fc $\gamma \mathrm{R}$-mediated cytokine induction is responsible for excessive inflammation as observed in autoimmune diseases that are associated with $\operatorname{IgG}$ autoantibodies, such as rheumatoid arthritis (RA) and systemic lupus erythematosus (SLE).

In general, most knowledge on $\mathrm{Fc} \gamma \mathrm{R}$ biology comes from mouse studies. Although various Fc $\gamma \mathrm{R}$ functions are conserved between species, both IgG subclasses and Fc $\gamma$ Rs differ in a number of aspects between mouse and man (5). These differences impede translation of findings for particular $\mathrm{F} c \gamma \mathrm{R}$ features from mouse studies to the human situation and vice versa. Importantly, the capacity of Fc $\gamma$ Rs to induce or modulate cytokine production appears to substantially differ between species, as summarized in Box 1. This difference is likely to be caused by differential 


\section{Box 1 | Fc $\gamma$ R-related differences between mouse and man.}

The orchestration of cytokine responses by activating low-affinity Fc $\gamma$ Rs clearly differs between humans and mice. Four key differences in this regard are summarized below.

- FcyRlla, which is the main FcyR responsible for the induction of pro-inflammatory cytokine production by human cells, is not expressed in mice (3-5).

- In various human cell types, including dendritic cells (DCs) and macrophages, stimulation with immune complexes induces Fc $\gamma \mathrm{R}$ dependent caspase-1 and inflammasome activation for the production of functional IL- $\beta(6,14,45)$. In contrast, in mice, immune complexes inhibit inflammasome activation and IL-1 $\beta$ production (93).

- In humans, the cytokine profile induced by cross-talk between activating Fc $\gamma$ Rs and co-receptors is predominantly characterized by various pro-inflammatory cytokines, of which TNF $\alpha$ upregulation is most pronounced $(6,7,14,45,59-61,71,72)$. In contrast, the cytokine profile induced by combined stimulation of murine DCs or macrophages with immune complexes and TLR ligands is characterized by elevated IL-10 and abrogated IL-12 production, whereas TNF $\alpha$ production is not affected or even reduced (14, 93-98).

- In humans, Fc $\gamma$ R-TLR cross-talk results in enhanced Th17 responses $(6,14)$, while in mice, Fc $\gamma$ R co-stimulation promotes Th2 responses $(93,96)$, which most likely results from the above mentioned differences in cytokine profiles by antigen-presenting cells.

expression of FcyRIIa, which is the main cytokine-inducing receptor in humans, but has no direct homolog in mice (3-5). In this review, we will therefore mainly focus on data from studies using human cells or humanized mouse models and their relevance to understanding and potential treatment of human diseases.

\section{CONTEXT-DEPENDENT CYTOKINE PRODUCTION BY Fc $\gamma$ Rs}

A key feature of $\mathrm{Fc} \gamma \mathrm{Rs}$ related to cytokine production is that $\mathrm{Fc} \gamma \mathrm{Rs}$ are unable to directly induce cytokines themselves, but instead collaborate with other receptors to amplify or inhibit the production of specific cytokines. The ultimate Fc $\gamma \mathrm{R}$-mediated cytokine profile is therefore not uniform, but instead appears to be tailored to the immunological context in which Fc $\gamma \mathrm{R}$ stimulation takes place. We here propose that this context-dependent cytokine production mediated by Fc $\gamma$ Rs is achieved through regulation at (at least) four levels.

First, the induced cytokine profile depends on the specific receptor that $\mathrm{F} c \gamma \mathrm{Rs}$ collaborate with. For example, cross-talk between FcyRIIa and TLRs, as occurs upon recognition of IgG opsonized bacteria, strongly amplifies production of proinflammatory cytokines such as TNF $\alpha$ (6). In contrast, Fc $\gamma$ Rs do not synergize with several cytokine receptors, including IL-6 receptor, IL-12 receptor, and IL-23 receptor (7). Second, the Fc $\gamma$ Rmediated cytokine response depends on the balance of activating versus inhibitory Fc $\gamma$ Rs. Indeed, it has been shown that stimulation of human DCs with IgG immune complexes simultaneously conveys an inflammatory signal by triggering activating receptor Fc $\gamma$ RIIa and a tolerogenic signal by triggering inhibitory receptor Fc $\gamma$ RIIb (8). Disturbances of this balance between activating and inhibitory Fc $\gamma$ Rs are associated with inflammation as observed in patients with bacterial infections or RA (9-11). Third, Fc $\gamma$ Rs are able to discriminate between aggregated (i.e., antigen-bound) and soluble IgG, thereby adding another layer of complexity to Fc $\gamma$ R-mediated cytokine modulation. For example, while large immune complexes are known to enhance cytokine production, stimulation of Fc $\gamma$ Rs with soluble IgG, as occurs under homeostatic conditions, results in inhibitory signaling that attenuates cytokine production $(12,13)$. Fourth, Fc $\gamma \mathrm{R}$ stimulation induces cell-intrinsic cytokine responses, thereby enabling cell-type and tissue-specific responses. For instance, while Fc $\gamma R$ R-TLR cross-talk enhances IL-10 production by DCs or macrophages, it attenuates
IL-10 production by monocytes (7). In this review, we will summarize and discuss these four levels of regulation of $\mathrm{F} \gamma \mathrm{R}$-mediated cytokine production by human innate immune cells in the context of three immunological states: homeostasis, infection, and autoimmunity.

\section{HOMEOSTASIS: INHIBITION OF CYTOKINE RESPONSES BY Fc $\gamma$ Rs}

In humans, three different $\mathrm{Fc} \gamma \mathrm{R}$ classes exist, which are $\mathrm{F} c \gamma \mathrm{RI}$ (CD64), Fc $\gamma$ RII (CD32), and Fc $\gamma$ RIII (CD16; see Figure 1). Fc $\gamma$ RI is the only high-affinity receptor, indicating that it is able to bind monomeric IgG molecules. In contrast, all other Fc $\gamma$ Rs are lowaffinity receptors and therefore require high-avidity binding by IgG immune complexes for appropriate binding and signaling (2-4). Fc $\gamma$ RI, Fc $\gamma$ RIIa, Fc $\gamma$ RIIc (expressed only in a minority of individuals), Fc $\gamma$ RIIIa, and Fc $\gamma$ RIIIb are categorized as activating receptors, which mostly signal via so-called immunoreceptor tyrosine-based activation motifs (ITAMs). These ITAMs are situated either in their Fc $\gamma$ R cytoplasmic tail (Fc $\gamma$ RIIa, Fc $\gamma$ RIIc) or in adaptor proteins such as the common $\gamma$-chain. In contrast, $\mathrm{Fc} \gamma \mathrm{RIIb}$ is the only known inhibitory Fc $\gamma \mathrm{R}$, which contains an immunoreceptor tyrosine-based inhibitory motif (ITIM) $(3,4)$.

Fc gamma receptors are widely expressed in virtually all hematopoietic cells, except for T cells. Most of these cells express both activating and inhibitory Fc $\gamma$ Rs, with the exception of NK cells (expressing solely Fc $\gamma$ RIII) and B cells (expressing solely Fc $\gamma$ RIIb) (3). Focusing on myeloid cells, monocytes express high levels of Fc $\gamma$ RI and Fc $\gamma$ RIIa, whereas Fc $\gamma$ RIIb is moderately expressed and Fc $\gamma$ RIII is expressed only on a subset of monocytes $(4,7)$. Both monocyte-derived DCs and DCs from blood express primarily Fc $\gamma$ RIIa and Fc $\gamma$ RIIb $(4,6-8)$. Macrophages express all classes of Fc $\gamma$ Rs, but particularly express high levels of Fc $\gamma$ RIIa (4, $7,14)$. In contrast, plasmacytoid DCs (pDCs) express Fc $\gamma$ Rs only at very low levels $(4,8)$. Here, we will first discuss the role of both inhibitory and activating Fc $\gamma$ Rs in homeostasis.

\section{FC $\gamma$ RIIb-MEDIATED INHIBITION OF CYTOKINE PRODUCTION}

Important for the control of cytokine production under homeostatic conditions is the balance between activating and inhibitory Fc $\gamma$ Rs. Studies in mice identified Fc $\gamma$ RIIb as the main inhibitory receptor for various $\mathrm{F} c \gamma \mathrm{R}$-mediated processes 


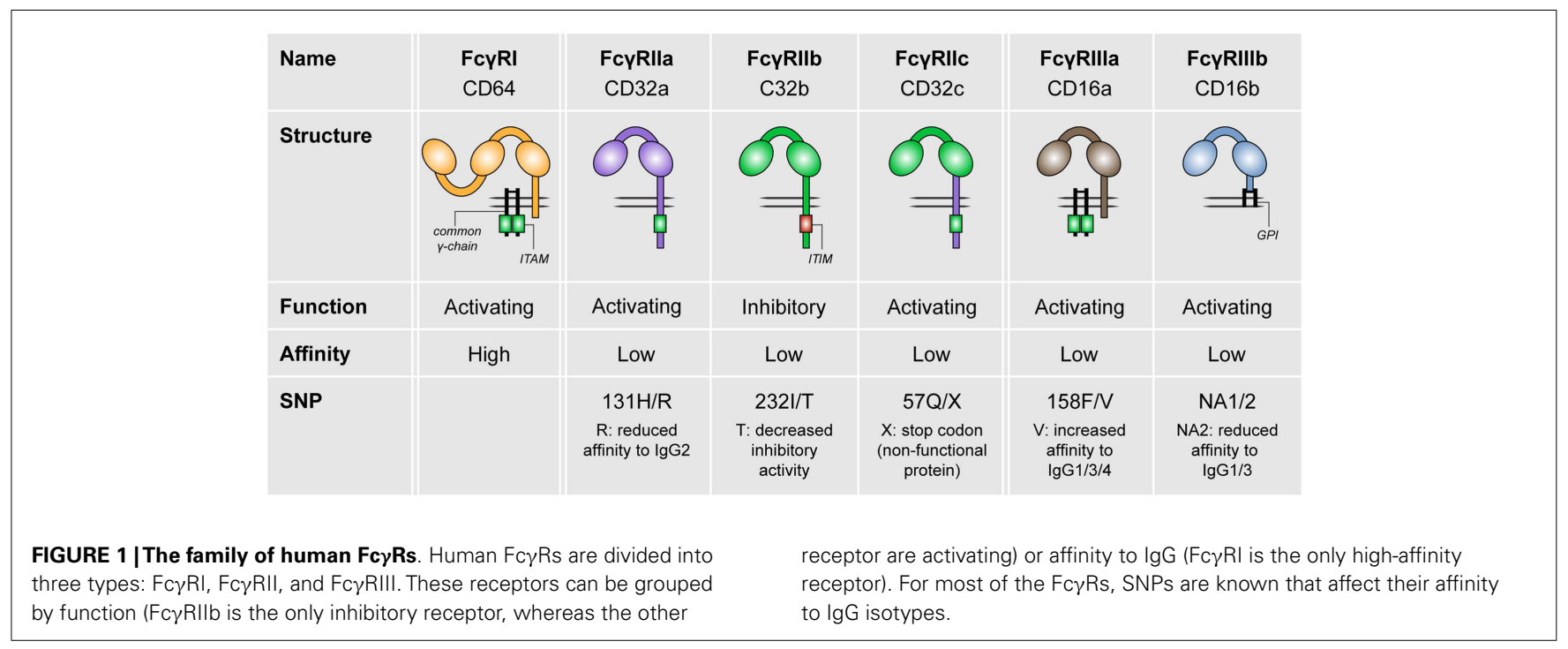

(3). ITIM-containing receptors, including Fc $\gamma$ RIIb, perform their inhibitory functions via recruitment of phosphatases, specifically Src homology 2 (SH2) domain-containing phosphatase-1 (SHP1) and $\mathrm{SH} 2$ domain-containing inositol phosphatase-1 (SHIP-1). These phosphatases are able to impede effector functions of ITAMbearing receptors, including activating Fc $\gamma$ Rs, by interfering with activation of a variety of kinases and adaptor proteins $(15,16)$.

The research on human Fc $\gamma$ RIIb took a leap forward upon the development of a specific Fc $\gamma$ RIIb-blocking antibody (8). Studies using human monocytes or DCs demonstrated that stimulation with IgG immune complexes, which simultaneously stimulate both activating and inhibitory Fc $\gamma$ Rs, hardly induce the production of any cytokines $(6,8,17-19)$. In contrast, selective blockade of FcyRIIb under these conditions induces production of numerous cytokines and chemokines, including TNF $\alpha$, IL-1 $\beta$, IL-6, IL-8, IL-12p70, and IL-23 (8, 18, 20), which consequently promotes T-cell responses (8). These data demonstrate that the balance between activating and inhibitory Fc $\gamma$ Rs (schematically depicted in Figure 2A) effectuates a threshold for cell activation and consequent immune responses.

Regulation of this balance critically depends on the relative cell surface expression of activating and inhibitory Fc $\gamma$ Rs, which in turn is dictated by factors in the direct surroundings of the immune cells. Exposure to soluble, monomeric IgG, as occurs under homeostatic conditions, selectively reduces the expression of Fc $\gamma$ RIIa on human DCs, thereby shifting the balance toward anti-inflammatory responses induced by inhibitory Fc $\gamma$ RIIb (Figure 2A). In contrast, exposure to IFN $\gamma$, as occurs under inflammatory conditions, results in decreased Fc $\gamma$ RIIb and increased $F c \gamma$ RI and Fc $\gamma$ RIIa expression, thereby tilting the balance toward the induction of inflammatory cytokine production (8). Taken together, ITIM-containing Fc $\gamma$ RIIb has a crucial role in regulating inflammatory responses under homeostatic conditions.

\section{ITAMi: INHIBITORY SIGNALING INDUCED BY CIRCULATING IgG}

Although inhibitory signals were initially only associated with Fc $\gamma$ Rs that bear an ITIM (i.e., solely Fc $\gamma$ RIIb) in the last decade, it has become clear that also ITAM-related receptors can negatively control inflammatory responses. This additional, antiinflammatory function of ITAMs has been denoted inhibitory ITAM (ITAMi) $(16,21)$. It has recently been shown that circulating IgG monomers, as abundantly present in serum, induce ITAMi signaling by binding to human low-affinity receptors Fc $\gamma$ RIIa (13) and Fc $\gamma$ RIII (12). Besides inhibiting TLR-induced calcium responses, endocytosis, phagocytosis, and reactive oxygen species production, this ITAMi signaling also inhibits the production of pro-inflammatory cytokines and chemokines by human monocytes or macrophages, including TNF $\alpha$, IL-6, and IL-8 (12, 13) (Figure 2B). Similar to ITIM-mediated inhibition, ITAMi-mediated inhibition requires SHP-1 recruitment (16). Subsequently, so-called inhibisomes are being formed, which are clusters containing Fc $\gamma$ Rs together with other receptors that are being inhibited, such as TLRs $(12,22)$. In addition, it has been described that small, soluble IgG complexes enhance TLR-induced anti-inflammatory IL-10 production by various subsets of human macrophages, whereas pro-inflammatory cytokines are not or hardly affected (23). However, it is yet unclear whether this elevated IL-10 production truly depends on ITAMi signaling.

In summary, FcyRs play an active role in the regulation of homeostasis, which is achieved by suppression of proinflammatory cytokine responses as well as promotion of IL10 production via both inhibitory receptor Fc $\gamma$ RIIb and ITAMi signaling of activating Fc $\gamma$ Rs.

\section{INFECTION: INDUCTION OF PRO-INFLAMMATORY CYTOKINES BY Fc $\gamma$ Rs}

Whereas Fc $\gamma$ Rs suppress pro-inflammatory cytokines under homeostatic conditions, they are crucial in promoting inflammation upon infection. The ultimate immune response by myeloid cells induced in response to pathogens is not the result of stimulation of one single receptor, but rather is induced by cross-talk or collaboration between multiple receptors $(24,25)$. This collaboration between receptors induces an intricate regulation of cytokine production that effectuates pathogen- and tissue-specific 


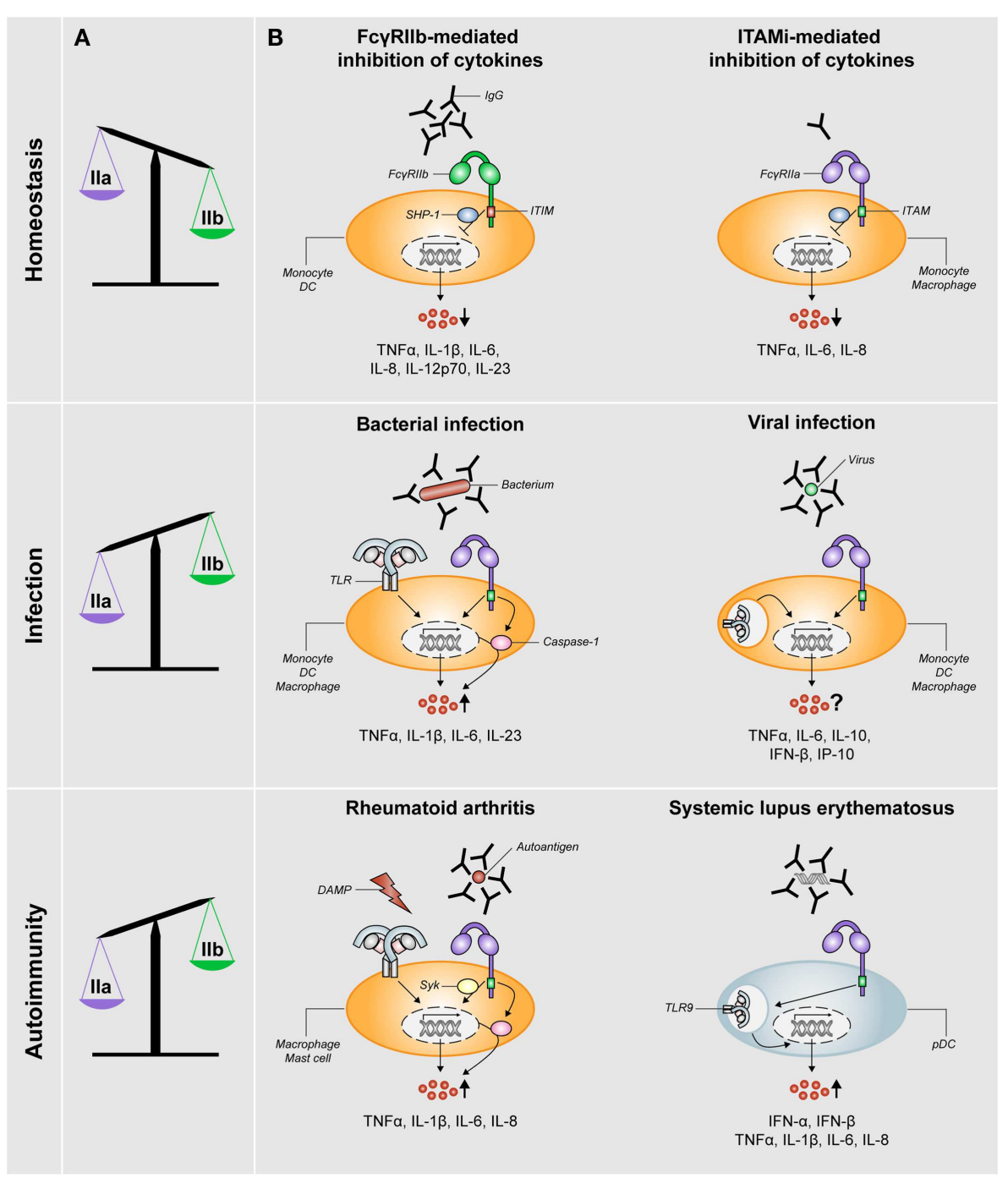

FIGURE 2 | Fc $\gamma$ RIla/b expression and Fc $\gamma$ R-mediated control of cytokine production during homeostasis, infection, and autoimmunity. (A) The balance of expression levels of activating Fc $\gamma$ RIla (Ila) and inhibitory Fc $\gamma$ RIIb (IIb) is skewed toward Fc $\gamma$ RIllb expression under homeostatic conditions, whereas it is skewed toward Fc $\gamma$ RIla under conditions of infection or autoimmunity (note: data on Fc $\gamma R$ expression in RA patients are not fully consistent, see main text). (B) FcyRs orchestrate cytokine production under different conditions. Homeostasis: pro-inflammatory cytokine production is inhibited via either ITIM-mediated signaling via SHP-1 (or SHIP-1) downstream of Fc $\gamma$ RIIb or ITAMi-mediated signaling downstream of activating Fc $\gamma$ Rs such as Fc $\gamma$ RIla. Infection: in the context of bacterial infections, specific pro-inflammatory cytokines are synergistically being upregulated (via upregulation of both transcription and caspase-1 activation) as a result of cross-talk between Fc $\gamma$ RIla and TLRs. For viral infections, the effect of simultaneous stimulation of $\mathrm{Fc} \gamma \mathrm{Rs}$ and TLRs recognizing viral structures on cytokine production is not yet clear. Autoimmunity: in RA, simultaneous stimulation of FcyRlla (via lgG autoantibody-containing immune complexes) and TLRs (via disease-associated DAMPs) induces cross-talk similar to that upon bacterial infection, which results in synergistic upregulation of specific pro-inflammatory cytokines in a Syk-dependent manner. In the context of SLE, disease-associated immune complexes are being taken up by pDCs in an Fc $\gamma$ RIla-dependent manner and subsequently delivered to TLR9-containing lysosomes, which results in upregulation of production of type I interferons and pro-inflammatory cytokines. immunity and prevents unbridled responses with detrimental effects.

Initially only PRRs, which recognize conserved microbial structures known as pathogen-associated molecular patterns (PAMPs), were considered to be able to induce innate response genes such as cytokines (26). However, recently it has become clear that also $\mathrm{Fc} \gamma$ Rs play a major role in control of cytokine production. Due to the high levels of IgG directed against numerous antigens, invading pathogens are efficiently opsonized when they penetrate the body's barriers, either directly during primary infection or at a later stage after generation of pathogen-specific IgG. Thus, in contrast to homeostatic conditions were IgG molecules are present in monomeric form, pathogen opsonization results in the formation of IgG complexes which can activate low-affinity receptors such as Fc $\gamma$ RIIa. Consequently, innate immune cells sense these opsonized pathogens via PRRs and Fc $\gamma$ Rs simultaneously. Although Fc $\gamma$ Rs 
do not directly induce pro-inflammatory cytokines when stimulated individually $(6,8,17-19)$, combined stimulation of Fc $\gamma$ Rs together with other receptors results in pathogen-specific cytokine responses. Below, we will discuss the role of $\mathrm{Fc} \gamma \mathrm{R}$-induced cytokine production in response to infection with different classes of pathogens.

\section{BACTERIAL INFECTIONS}

Immunoglobulin $\mathrm{G}$ seems to particularly play an important role in defense against bacteria, as patients with primary antibody deficiencies mainly suffer from bacterial infections, but hardly from fungal or viral infections (27). In healthy individuals, high amounts of cross-reactive IgG directed to bacterial antigens are present and consequently bacteria are efficiently being opsonized, even during primary infection (6). Importantly, Fc $\gamma$ RII expression on monocytes and neutrophils is increased in patients with bacterial infections, compared to healthy controls or patients with viral infections (11). In addition, stimulation of TLR2 or TLR4, which predominantly recognize bacterial PAMPs, has been described to induce Fc $\gamma$ RIIa expression on human monocytes (28). These findings indicate that exposure to bacteria makes myeloid cells more prone to recognize complexed IgG structures such as opsonized bacteria (Figure 2A).

Recent data show that cytokine induction by Fc $\gamma$ RIIa plays an important role in directing antibacterial responses. IgG opsonization of various bacteria such as Staphylococcus aureus or Klebsiella pneumoniae strongly increases the production of particular proinflammatory cytokines by DCs, such as IL-1 $\beta$, IL-6, IL-23, and $\mathrm{TNF} \alpha$, but not IL-12 (6). Induction of this specific cytokine profile skews $\mathrm{T}$ helper cell responses toward Th17, which is required for efficient eradication of extracellular pathogens and therefore appears to function as a natural mechanism to counteract bacterial infections. This synergistic cytokine response fully depends on cross-talk between Fc $\gamma$ RIIa and TLRs, which are activated simultaneously on DCs upon encountering IgG opsonized bacteria. Mechanistically, Fc $\gamma$ RIIa-TLR cross-talk in DCs is mediated by both enhancing the transcription of specific cytokine genes and via activation of caspase-1, which cleaves pro-IL- $1 \beta$ into its bioactive form (6). Besides DCs, Fc $\gamma$ RIIa-TLR cross-talk also occurs in human monocytes and macrophages (7), indicating that this antibacterial mechanism is functional in multiple myeloid cell types (Figure 2B). In addition, several reports suggest that Fc $\gamma$ Rs and TLRs do not necessarily need to be activated simultaneously for this synergistic effect, since overnight activation of monocytes or DCs followed by stimulation with aggregated IgG still strongly increases TNF $\alpha$ production $(10,28,29)$.

Monocytes exposed to IFN $\gamma$ appear to have an additional, indirect mechanism of immune complex-dependent cytokine production. Upon LPS stimulation, exposure of these cells to immune complexes downregulates IL-10 receptor expression and inhibits IL-10 signaling in an Fc $\gamma$ RI-dependent manner, which results in enhanced TNF $\alpha$ and IL-6 production (30). Importantly, this IL-10 loop was only observed in monocytes polarized in the presence of IFN $\gamma$, which induces Fc $\gamma$ RI expression, but not upon M-CSFinduced differentiation (30), which stresses the importance of cytokines and differentiation factors in the micro-environment of immune cells for Fc $\gamma$ R-mediated effects.
The importance of Fc $\gamma$ RIIa in antibacterial responses is further emphasized by studies on the FCGR2A single nucleotide polymorphism (SNP) H131R. This SNP strongly affects binding affinity of the receptor to IgG2, the main isotype that is reactive to bacterial antigens (31). Multiple studies [reviewed by Van Sorge et al. (32)] indicate that FCGR2A-R131 homozygous individuals, carrying the receptor with low IgG2 affinity, are more susceptible to bacterial infections. However, this difference is unlikely to be caused by differences in Fc $\gamma$ R-induced cytokine production, since Fc $\gamma$ RIIa-TLR cross-talk is completely functional in DCs from FCGR2A-R131 homozygous individuals (7). Instead, this difference in susceptibility to bacterial infections may be explained by the finding that FCGR2A-R131 impairs IgG2-mediated phagocytosis (33). Apparently, while the low affinity for IgG2 of Fc $\gamma$ RIIa-131R impairs uptake of opsonized bacteria, the binding of large IgG2 complexes is still sufficient to induce cytokines. This finding strengthens the idea that Fc $\gamma$ RIIa-mediated cytokine production and uptake are regulated via distinct mechanisms.

The relevance of Fc $\gamma \mathrm{R}$-mediated cytokine responses in combating bacteria is also indirectly indicated by the existence of immune escape mechanisms to evade this response. Interestingly, Streptococcus pyogenes produces Endoglycosidase $S$, an enzyme that is able to hydrolyze the heavy chain glycan of IgG molecules. As a result, the binding of IgG to Fc $\gamma$ RIIa was strongly reduced (34), which impairs the antibacterial immune response. Additionally, $S$. aureus secretes a potent Fc $\gamma$ RII antagonists, formyl peptide receptor-like 1 inhibitor (FLIPr) that competitively blocks IgG binding and subsequent IgG-mediated antibacterial effector functions (35).

Notably, Fc $\gamma$ R-dependent control of cytokine production may not only depend on the presence of IgG. Also, members of the pentraxin family such as C-reactive protein (CRP) are known to interact with FcyRs. CRP is an acute-phase protein that is rapidly synthesized by the liver upon injury or infection and it is known to bind phosphocholine that is expressed on the surface of particular bacteria (36). It has been reported that CRP increases cytokine production, predominantly TNF $\alpha$ and IL- $1 \beta$, by PBMC in response to $S$. pneumoniae via Fc $\gamma$ RI and Fc $\gamma$ RIIa (37).

In conclusion, Fc $\gamma$ Rs are critically involved in counteracting bacterial infections. Particularly, cross-talk between Fc $\gamma$ RIIa and bacterial component recognizing TLRs in human myeloid cells selectively promotes the production of pro-inflammatory cytokines that play a crucial role in antibacterial immunity, such as TNF $\alpha$ and various Th17-promoting cytokines.

\section{FUNGAL INFECTIONS}

In contrast to bacterial infections, currently still little is known about the contribution of $\mathrm{Fc} \gamma \mathrm{Rs}$ to cytokine production in antifungal immune responses. However, it is known that opsonization of Candida albicans synergistically increases the production of $\mathrm{TNF} \alpha$ by human monocytes or PBMC. This effect was largely dependent on extracellular signal-regulated kinases (ERK) (38). Fungi are recognized through multiple PRRs, including TLRs and C-type lectin receptors. Dectin-1 is one of the main cytokineinducing C-type lectin receptors, which strongly contributes to antifungal immunity (26). However, Fc $\gamma \mathrm{R}$ co-stimulation with immobilized IgG does not enhance Dectin-1-induced TNF $\alpha$ production (7). This indicates that increased TNF $\alpha$ production upon 
exposure to opsonized C. albicans is likely to be dependent on cross-talk of Fc $\gamma$ Rs with TLRs, rather than with C-type lectin receptors. Furthermore, it strengthens the concept that Fc $\gamma$ R stimulation does not simply enhance cytokine production induced by any given receptor, but instead specifically collaborates with particular (families of) receptors.

\section{VIRAL INFECTIONS}

The main focus of research on the role of antibodies and Fc $\gamma$ Rs during viral infections has been on virus neutralization, ADCC, antibody-dependent enhancement of infection, and phagocytosis, while data on $\mathrm{F} c \gamma \mathrm{R}$-mediated cytokine responses in the context of viral infections is limited as well as conflicting. Recently, it has been shown that monocytes, DCs, and macrophages strongly upregulate TNF $\alpha$ and IL- 6 production upon exposure to serumopsonized Dengue virus, in an Fc $\gamma$ RIIa-dependent manner (39). This is likely to be due to cross-talk of TLR3 and TLR7/8, recognizing virus-associated double-stranded or single-stranded RNA respectively, with Fc $\gamma$ RIIa, as has been described recently (7). Others have confirmed upregulation of IL-6, as well as IL-10, upon serum-opsonized Dengue virus in a human monocytic cell line on both mRNA and protein level (40-42). In contrast, TNF $\alpha$ as well as IL-12 were reported to be downregulated in this assay (40).

Besides pro-inflammatory cytokines such as TNF $\alpha$ and IL-6, other cytokines and chemokines, particularly type I interferons and related chemokines, may be of great relevance in the context of viral infections (43). However, the effect of Fc $\gamma$ RIIa (co-)ligation on these specific cytokines and chemokines has hardly been studied. The scarce data on this topic is not conclusive, as one study showed upregulation of IFN $\alpha$ and IFN $\beta$ by macrophages upon stimulation with opsonized Dengue virus (39) while others reported downregulation of IFN $\beta$ protein by a monocytic cell line upon Dengue opsonization (42). Interestingly, Posch and colleagues recently reported that exposure of DCs to opsonized HIV results in a decreased HIV-specific $\mathrm{CD}^{+}{ }^{+} \mathrm{T}$-cell response, in an FcyRIIa-dependent way. However, to which extent this effect was dependent on cytokines produced by DCs has not been studied (44). In conclusion, the role of Fc $\gamma$ Rs in cytokine production during viral infections (Figure 2B), and to what extend cytokine modulation is beneficial to the host or to the virus, is not yet clear.

\section{PARASITIC INFECTIONS}

Recently, it was shown that erythrocytes infected with malariacausing Plasmodium falciparum promote pro-inflammatory cytokines once opsonized with IgG. Particularly, opsonized infected erythrocytes, compared to unopsonized cells, induce high TNF $\alpha$, IL- $1 \beta$, and IL- 6 production by human macrophages (45). Remarkably, the role of $\mathrm{TNF} \alpha$ and other pro-inflammatory cytokines in parasitic infections, including $P$. falciparum, is ambiguous: $\mathrm{TNF} \alpha$ has been identified to promote parasite killing, but it also contributes to development of severe malaria disease (46). Interestingly, the upregulation of pro-inflammatory cytokines was not transcriptionally regulated (45), in contrast to what was observed in DCs in response to opsonized bacteria (6). Induction of IL- $1 \beta$ upon exposure to opsonized infected erythrocytes was shown to be the result of Fc $\gamma \mathrm{R}$-induced inflammasome activation (45), which is in agreement with previous studies using both DCs and M2 macrophages $(6,14)$. Although data on Fc $\gamma$ Rmediated cytokines in antiparasitic responses is limited, it appears that similar to bacterial infections, IgG opsonization promotes specific pro-inflammatory cytokines upon parasitic infection.

\section{AUTOIMMUNITY: UNDESIRED Fc $\gamma$ R-INDUCED CYTOKINE PRODUCTION}

Although collaboration of $\mathrm{Fc} \gamma \mathrm{Rs}$ with other receptors to promote cytokine responses is beneficial in combating infections, undesired activation of this mechanism may contribute to the development of autoimmunity. RA, SLE, and several other autoimmune diseases are characterized by the presence of IgG autoantibodies and $\mathrm{F} c \gamma \mathrm{R}$ involvement in pathogenesis (47-49). In these diseases, IgG autoantibody-containing immune complexes can function as a danger signal that activates innate immune cells. We will here discuss the evidence of Fc $\gamma$ R-mediated cytokine production in the context of several autoimmune diseases.

\section{RHEUMATOID ARTHRITIS}

RA is a chronic autoimmune disease occurring in 1\% of the population and is characterized by inflammation and damage of the joints (50). Although the pathogenesis of RA is far from fully understood, it is clear that pro-inflammatory cytokines, predominantly $\mathrm{TNF} \alpha$, have a crucial role in the inflammatory process, as is emphasized by the great clinical improvement after neutralization of these cytokines (50). In recent years, the presence of autoantibodies, which is one of the hallmarks of RA, is beginning to be recognized as a contributing factor in inflammation and joint damage via the production of pro-inflammatory cytokines. The most prominent type of autoantibodies present in RA patients is anti-citrullinated protein antibodies (ACPA), which are present long before onset of disease symptoms and are mainly of the IgG isotype $(49,51,52)$. Upon recognition of their antigen, e.g., citrullinated extracellular matrix proteins in the joint, autoantibodies form large, insoluble, and amorphous immune complexes (52) that enable their recognition by low-affinity $\mathrm{Fc} \gamma \mathrm{Rs}$.

The importance of Fc $\gamma$ Rs in RA pathogenesis is indicated by various studies using mouse models for arthritis [reviewed by El Bannoudi et al. (49)], of which the use of human Fc $\gamma$ RIIa transgenic mice may be the most relevant (53). These transgenic mice display a higher susceptibility to collagen-induced arthritis and developed more severe arthritis than wild-type mice (53, 54). Importantly, in a passive antibody transfer model, all Fc $\gamma$ RIIa transgenic mice develop arthritis, while none of the control animals are affected. In addition, these transgenic mice spontaneously develop multi-organ autoimmunity (53).

In the context of RA, Fc $\gamma$ R stimulation on myeloid cells has been shown to induce pro-inflammatory cytokines that are pivotal in RA pathogenesis, including TNF $\alpha$, IL-1 $\beta$, and IL-6. Precipitated or plate-bound IgG from serum or synovial fluid of RA patients, without any additional stimulus, induces TNF $\alpha$ production by healthy donor PBMC, predominantly monocytes, in an Fc $\gamma$ RIIa-dependent manner (55-57). However, in these experiments, the resulting levels of $\mathrm{TNF} \alpha$ were rather low (picogramrange), which indicates the marginal capacity of $\mathrm{Fc} \gamma \mathrm{Rs}$ to induce cytokine production when stimulated without any co-stimulation. Similar to their role in pathogen defense, Fc $\gamma$ Rs essentially need 
to collaborate with other families of receptors for the induction of physiological relevant cytokine responses. In RA synovia, this "second signal" most likely originates from the family of TLRs. Besides recognition of pathogens, TLR activation can occur through recognition of endogenous ligands, also referred to as damageassociated molecular patterns (DAMPs). These are abundantly present in RA synovia as a result of tissue damage and cell death (58). Indeed, activation of macrophages with IgG immune complexes-containing citrullinated fibrinogen, which activates both Fc $\gamma$ RIIa and TLR4, strongly induces the production of TNF $\alpha$ (59-61) (Figure 2B). A similar effect of Fc $\gamma$ RIIa-TLR cross-talk has been observed in human mast cells, which results in synergistic upregulation of IL-8 production (62).

In addition, Fc $\gamma$ R-TLR cross-talk may promote inflammation in RA patients by interfering with the immunosuppressive function of M2 macrophages. Although macrophages are a heterogeneous population of cells that can differentiate into a full spectrum of different phenotypes, macrophages are generally being categorized into either M1 macrophages, which are classically activated macrophages with pro-inflammatory properties, or M2 macrophages, which display anti-inflammatory, regulatory, and/or wound healing properties. Importantly, while M2 macrophages are known to suppress inflammation in disorders such as tumor formation, atherosclerosis, and obesity (63), in RA patients Fc $\gamma$ R-TLR cross-talk converts M2 macrophages to promote inflammation (14). While the general phenotype of M2 macrophages is retained, stimulation of these cells with IgG immune complexes and TLR ligands induces the selective induction of RA-associated cytokines TNF $\alpha$, IL-1 $\beta$, and IL-6, and promotes Th17 responses, in a spleen tyrosine kinase (Syk)-dependent way (14). Since the conventional function of M2 macrophages, i.e., preventing disproportionate immune activation and mediating tissue repair, is abrogated, this may thereby contribute to excessive inflammation as observed in RA patients.

Considered the importance of the balance of activating versus inhibitory Fc $\gamma$ Rs in controlling inflammation, numerous studies have investigated $\mathrm{Fc} \gamma \mathrm{R}$ expression levels on immune cells of RA patients. However, the data on this are far from consistent. Some studies found no differences between RA patients and healthy controls (60,64-66), whereas others reported that monocytes, moDCs, monocyte-derived macrophages, and synovial macrophages of RA patients displayed elevated levels of activating receptors Fc $\gamma$ RIIa and Fc $\gamma$ RIII, while expression of inhibitory receptor Fc $\gamma$ RIIb was similar to healthy controls (9, 10, 29, 57, 67, 68) (Figure 2A). The reasons for these inconsistent findings are still unclear, but may involve differences in the stage of disease, donor variation, and disease heterogeneity.

Taken together, the body of evidence for a causative role of Fc $\gamma$ Rs, predominantly in synergy with TLRs, in the induction of inflammation in RA is increasing. As such, these data support the concept that the occurrence of IgG autoantibodies is not merely an epiphenomenon, but in fact actively contributes to RA pathogenesis.

\section{SYSTEMIC LUPUS ERYTHEMATOSUS}

Another well-known IgG immune complex associated autoimmune disease is SLE. SLE is a chronic, systemic autoimmune disease that can affect virtually any organ, but primarily kidneys, skin, lungs, brain, and heart. SLE is characterized by autoantibodies to DNA, RNA, and other nuclear structures. The key cytokine in the inflammatory process in SLE is considered to be IFN $\alpha$, which is mainly produced by pDCs $(48,69)$. A meta-analysis covering 17 studies revealed that FCGR2A-R131 is a significant risk factor for SLE (70), suggesting Fc $\gamma$ RIIa is involved in SLE pathogenesis. Furthermore, it is known that ligation of TLR7 and 9, which are endosomal receptors that recognize RNA and DNA structures and are constitutively expressed by $\mathrm{pDCs}$, induces IFN $\alpha$ production. The localization of TLR7 and 9 in the endosomal compartment ensures that under physiological conditions, these TLRs are shielded from self-RNA or self-DNA at the exterior of cells, for example from dying cells (69).

Fc $\gamma$ RIIa has been shown to be important in inducing IFN $\alpha$ in SLE patients, via cooperation with TLRs. Means and colleagues elegantly showed that Fc $\gamma$ RIIa facilitates uptake of DNA-containing immune complexes and delivery to intracellular lysosomes comprising TLR9 in human pDCs (71). This Fc $\gamma$ RIIa-dependent activation of TLR9 results in production of IFN $\alpha$, as well as other cytokines and chemokines such as TNF $\alpha$, IL-1 $\beta$, IL-6, and IL-8 (71, 72) (Figure 2B). Interestingly, this mechanism of Fc $\gamma$ RIIa-induced upregulation of cytokines in pDCs differs from that in other cell types. While in pDCs the amplification of TLR-induced cytokine production critically depends on Fc $\gamma$ RIIa-dependent uptake of immune complexes (71), cytokine production by Fc $\gamma$ RIIa in DCs and macrophages is independent of uptake $(6,14)$. Thus, although via a different mechanism and in a different cell-type than in RA, Fc $\gamma$ RIIa also contributes to the pathogenesis of SLE via amplification of cytokine production.

\section{SYSTEMIC SCLEROSIS}

Systemic sclerosis (SSc) or scleroderma is a heterogeneous autoimmune connective tissue disease of unknown etiology, which is characterized by excessive fibrosis in the skin and internal organs, vasculopathy, and immune abnormalities. Autoantibodies are present in more than $95 \%$ of SSc patients, which are directed against a variety of nuclear, cytoplasmic, and extracellular autoantigens (73). In addition, SSc is characterized by the release of endogenous TLR ligands, which form immune complexes by the binding of autoantibodies (74). Reminiscent of what has been observed in pDCs for SLE immune complexes (71), stimulation with SSc immune complexes induces IFN $\alpha$ production by PBMC, which is dependent on Fc $\gamma$ RII-mediated uptake of immune complexes and the presence of RNA, suggesting involvement of TLR7 (75). Similar to SLE, this mechanism may contribute to the IFN type gene "signature" as observed in many SSc patients (76).

\section{OTHER AUTOIMMUNE DISEASES}

Besides RA, SLE, and SSc, Fc $\gamma$ R-dependent modulation of cytokine production may play a role in the pathogenesis of several other disorders characterized by IgG autoantibodies. In principle, Fc $\gamma$ R-TLR cross-talk can be induced in any disorder involving immune complexes, endogenous TLR ligands, and Fc $\gamma \mathrm{R}$ - and TLR-expressing immune cells. Although there is little direct evidence, several diseases are likely to fulfill these criteria, including Sjögren's syndrome, pemphigus, and multiple sclerosis (77-80). 
Future studies are required to elucidate whether and to what extent $\mathrm{Fc} \gamma \mathrm{R}$-mediated cytokine production indeed is involved in these autoimmune diseases.

\section{MODULATION OF FC $\gamma$ R-INDUCED CYTOKINE PRODUCTION: OPPORTUNITIES FOR THERAPEUTIC INTERVENTION}

We have discussed that stimulation of Fc $\gamma$ Rs with IgG immune complexes, predominantly in cooperation with PRRs such as TLRs, promote inflammatory cytokine responses. On one hand, this is beneficial to the host, since it allows us to efficiently counteract infections with bacteria and possibly also other classes of pathogens. On the other hand, activation of this mechanism can also have detrimental effects, since it may promote inflammatory responses leading to autoimmunity. Therefore, modulation of Fc $\gamma$ R-induced cytokine production in the context of infection and autoimmunity may provide opportunities for therapeutic intervention, either by reducing or by enhancing these inflammatory responses.

An important example of Fc $\gamma$ R-related therapy is the use of intravenous immunoglobulin (IVIG). IVIG was initially used as an IgG replacement therapy for immunocompromised patients, but paradoxically also has general anti-inflammatory effects. Our understanding of the anti-inflammatory effect of IVIG is still far from complete and is beyond the scope of this review. Excellent reviews by others $(81,82)$ summarize several modes of action of IVIG in autoimmunity, including blockade of interaction of immune complexes with activating low-affinity Fc $\gamma$ Rs. Moreover, IVIG administration modulates the balance between activating and inhibitory Fc $\gamma$ Rs, predominantly as a result of increased expression of inhibitory receptor Fc $\gamma$ RIIb $(81,82)$. In addition, recently it has been described that IVIG preparations contain anti-Fc $\gamma$ RII and anti-Fc $\gamma$ RIII antibodies (83), which may interfere with binding of these Fc $\gamma$ Rs to disease-associated autoantibody structures.

An alternative approach to interfere with Fc $\gamma$ R-mediated inflammation is to specifically provide IgG molecules that preferentially bind to and activate the inhibitory receptor Fc $\gamma$ RIIb. Indeed, recently an anti-CD19 antibody carrying an Fc region with over 400 times greater affinity to Fc $\gamma$ RIIb compared to F $\gamma$ RIIa has been engineered (84). Co-engaging of the B-cell receptor complex together with Fc $\gamma$ RIIb by this engineered antibody suppressed B-cell activation and function, including IgG secretion and IL6 production (85-87), which therefore may be of therapeutic benefit in IgG-mediated autoimmune diseases such as RA and SLE.

Moreover, it may be promising to specifically interfere with downstream molecules involved in Fc $\gamma \mathrm{R}$-modulated cytokine production. Although the mechanism of Fc $\gamma$ R-modulated cytokine production is still largely unidentified, Syk is known to be pivotal for cytokine production induced by Fc $\gamma$ RIIa-TLR cross-talk (14). Interestingly, therapeutic inhibition of Syk using oral small molecule inhibitor R788 indeed significantly reduces disease activity in RA patients (88). Although Syk is probably also required for other immunological processes, these trials illustrate the potential therapeutic possibilities of interfering with $\mathrm{Fc} \gamma \mathrm{R}$-induced cytokine production. Similarly, identification of other key signaling molecules of Fc $\gamma \mathrm{R}$ cross-talk in the future may give rise to additional targets for therapy that could be blocked using small molecule inhibitors.

While inhibition of Fc $\gamma$ R-induced cytokine production may be beneficial to attenuate inflammation in autoimmunity, enhancing inflammation may be useful in the context of bacterial infections or solid tumors. Considered its ability to amplify the induction of Th17 responses by antigen-presenting cells such as DCs, an adjuvant that would simultaneously cross-link activating low-affinity Fc $\gamma$ Rs and TLRs may function as a powerful new vaccination strategy for establishing effective antibacterial memory responses. In addition, during both chronic bacterial infections and solid tumors, the local environment is dominated by the presence of anti-inflammatory or suppressive M2 macrophages, which attenuate the generation of effective antibacterial or antitumor immune responses $(63,89,90)$. As Fc $\gamma$ R-TLR cross-talk is known to elicit pro-inflammatory cytokine responses by M2 macrophages (14), local induction of this response may greatly enhance the induction of antitumor immunity. Since IgG antibody therapy is already used for the treatment of solid tumors (91), the coupling of TLR agonists to these IgG antibodies for the local induction of inflammation may be a very useful tool to further enhance the efficacy of current treatments.

Taken together, additional knowledge on the specific cytokine profile induced by different cell types and the identification of the underlying molecular mechanisms are promising subjects for future research, since this may lead to novel therapeutic strategies for a large variety of disorders, including chronic (bacterial) infections, tumor formation, and IgG autoantibody-associated autoimmune diseases.

\section{CONCLUDING REMARIKS}

Here, we have described and discussed a novel function of human Fc $\gamma$ Rs in shaping cytokine responses and thereby orchestrating context-dependent immunity. Although the cytokine profile induced by stimulation of activating $\mathrm{Fc} \gamma \mathrm{Rs}$ varies depending on the cell-type and the combination of stimuli, it appears that TNF $\alpha$ is the key cytokine that is being upregulated in almost all cell types in response to $\mathrm{Fc} \gamma \mathrm{R}$ co-stimulation. An important remaining question is the identity of the (classes of) receptors are able collaborate with Fc $\gamma$ Rs for the amplification (or inhibition) of cytokine production. Thus far, Fc $\gamma$ Rs have been shown to synergize with TLRs, IFN $\gamma$ receptor, and IL-1 receptor, but not with various other cytokine receptors or C-type lectins (7). Alternatively, besides Fc $\gamma$ Rs also other classes of Fc receptors, including $\mathrm{F} c \varepsilon \mathrm{R}$ and $\mathrm{F} c \alpha \mathrm{R}$, may affect cytokine production upon collaboration with PRRs or other receptors (92). Further identification of collaborating and non-collaborating receptors will offer new insights into the shaping of cytokine responses by myeloid cells and thereby may provide new perspectives for future therapies.

While in this review we have completely focused on the cytokine shaping properties of $\mathrm{Fc} \gamma \mathrm{Rs}$, it is important to realize that $\mathrm{Fc} \gamma \mathrm{Rs}$ are responsible for many other processes, including uptake, antigen presentation, and ADCC. Therefore, in view of vaccination or other therapeutic strategies, it would be useful to specifically interfere with one aspect of Fc $\gamma$ R-mediated effects, while leaving other functions intact. In this regard, the recent findings that indicate that Fc $\gamma \mathrm{R}$-mediated phagocytosis and cytokine production 
are regulated via distinct mechanisms may provide valuable clues. However, to fully exploit these differences, more knowledge about mechanistic properties of these different $F c \gamma R$ functions in the human immune system is required.

\section{ACKNOWLEDGMENTS}

We would like to thank Martien L. Kapsenberg for critically reading the manuscript. JdD is supported by a grant from the Netherlands Organization for Scientific Research (NWO; VENI, project no. 91611012).

\section{REFERENCES}

1. Iwasaki A, Medzhitov R. Regulation of adaptive immunity by the innate immune system. Science (2010) 327:291-5. doi:10.1126/science.1183021

2. Vidarsson G, Dekkers G, Rispens T. IgG subclasses and allotypes: from structure to effector functions. Front Immunol (2014) 5:520. doi:10.3389/fimmu.2014. 00520

3. Nimmerjahn F, Ravetch JV. Fcgamma receptors as regulators of immune responses. Nat Rev Immunol (2008) 8:34-47. doi:10.1038/nri2206

4. Guilliams M, Bruhns P, Saeys Y, Hammad H, Lambrecht BN. The function of Fcgamma receptors in dendritic cells and macrophages. Nat Rev Immunol (2014) 14:94-108. doi:10.1038/nri3582

5. Lux A, Nimmerjahn F. Of mice and men: the need for humanized mouse models to study human IgG activity in vivo. J Clin Immunol (2013) 33(Suppl 1):S4-8. doi:10.1007/s10875-012-9782-0

6. den Dunnen J, Vogelpoel LT, Wypych T, Muller FJ, de BL, Kuijpers TW, et al. IgG opsonization of bacteria promotes Th17 responses via synergy between TLRs and FcgammaRIIa in human dendritic cells. Blood (2012) 120:112-21. doi:10.1182/blood-2011-12-399931

7. Vogelpoel LT, Hansen IS, Visser MW, Nagelkerke SQ, Kuijpers TW, Kapsenberg ML, et al. FcgammaRIIa cross-talk with TLRs, IL-1R, and IFNgammaR selectively modulates cytokine production in human myeloid cells. Immunobiology (2015) 220:193-9. doi:10.1016/j.imbio.2014.07.016

8. Boruchov AM, Heller G, Veri MC, Bonvini E, Ravetch JV, Young JW. Activating and inhibitory IgG Fc receptors on human DCs mediate opposing functions. J Clin Invest (2005) 115:2914-23. doi:10.1172/JCI24772

9. Blom AB, Radstake TR, Holthuysen AE, Sloetjes AW, Pesman GJ, Sweep FG, et al. Increased expression of Fcgamma receptors II and III on macrophages of rheumatoid arthritis patients results in higher production of tumor necrosis factor alpha and matrix metalloproteinase. Arthritis Rheum (2003) 48:1002-14. doi:10.1002/art.10871

10. Radstake TR, Blom AB, Sloetjes AW, van Gorselen EO, Pesman GJ, Engelen L, et al. Increased FcgammaRII expression and aberrant tumour necrosis factor alpha production by mature dendritic cells from patients with active rheumatoid arthritis. Ann Rheum Dis (2004) 63:1556-63. doi:10.1136/ard.2003.016550

11. Nuutila J, Jalava-Karvinen P, Hohenthal U, Kotilainen P, Pelliniemi TT, Nikoskelainen J, et al. A rapid flow cytometric method for distinguishing between febrile bacterial and viral infections. J Microbiol Methods (2013) 92:64-72. doi:10.1016/j.mimet.2012.11.005

12. Aloulou M, Ben Mkaddem S, Biarnes-Pelicot M, Boussetta T, Souchet H, Rossato E, et al. IgG1 and IVIg induce inhibitory ITAM signaling through FcgammaRIII controlling inflammatory responses. Blood (2012) 119:3084-96. doi:10.1182/blood-2011-08-376046

13. Ben Mkaddem S, Hayem G, Jonsson F, Rossato E, Boedec E, Boussetta T, et al. Shifting FcgammaRIIA-ITAM from activation to inhibitory configuration ameliorates arthritis. J Clin Invest (2014) 124:3945-59. doi:10.1172/JCI74572

14. Vogelpoel LT, Hansen IS, Rispens T, Muller FJ, van Capel TM, Turina MC, et al. Fc gamma receptor-TLR cross-talk elicits pro-inflammatory cytokine production by human M2 macrophages. Nat Commun (2014) 5:5444. doi:10.1038/ ncomms 6444

15. Huang ZY, Hunter S, Kim MK, Indik ZK, Schreiber AD. The effect of phosphatases SHP-1 and SHIP-1 on signaling by the ITIM- and ITAM-containing Fc $\gamma$ receptors Fc $\gamma$ RIIB and Fc $\gamma$ RIIA. J Leukoc Biol (2003) 73:823-9. doi:10.1189/ jlb.0902454

16. Blank U, Launay P, Benhamou M, Monteiro RC. Inhibitory ITAMs as novel regulators of immunity. Immunol Rev (2009) 232:59-71. doi:10.1111/j.1600-065X. 2009.00832.x
17. Banki Z, Kacani L, Mullauer B, Wilflingseder D, Obermoser G, Niederegger $\mathrm{H}$, et al. Cross-linking of CD32 induces maturation of human monocytederived dendritic cells via NF-kappa B signaling pathway. J Immunol (2003) 170:3963-70. doi:10.4049/jimmunol.170.8.3963

18. Dhodapkar KM, Banerjee D, Connolly J, Kukreja A, Matayeva E, Veri MC, et al. Selective blockade of the inhibitory Fcgamma receptor (FcgammaRIIB) in human dendritic cells and monocytes induces a type I interferon response program. J Exp Med (2007) 204:1359-69. doi:10.1084/jem.20062545

19. Dai X, Jayapal M, Tay HK, Reghunathan R, Lin G, Too CT, et al. Differential signal transduction, membrane trafficking, and immune effector functions mediated by FcgammaRI versus FcgammaRIIa. Blood (2009) 114:318-27. doi:10.1182/blood-2008-10-184457

20. Dhodapkar KM, Kaufman JL, Ehlers M, Banerjee DK, Bonvini E, Koenig S, et al. Selective blockade of inhibitory Fcgamma receptor enables human dendritic cell maturation with IL-12p70 production and immunity to antibodycoated tumor cells. Proc Natl Acad Sci U S A (2005) 102:2910-5. doi:10.1073/ pnas.0500014102

21. Ivashkiv LB. How ITAMs inhibit signaling. Sci Signal (2011) 4:e20. doi:10.1126/ scisignal.2001917

22. Pfirsch-Maisonnas S, Aloulou M, Xu T, Claver J, Kanamaru Y, Tiwari M, et al. Inhibitory ITAM signaling traps activating receptors with the phosphatase SHP-1 to form polarized "inhibisome” clusters. Sci Signal (2011) 4:ra24. doi:10.1126/scisignal.2001309

23. Ambarus CA, Santegoets KC, van Bon L, Wenink MH, Tak PP, Radstake TR, et al. Soluble immune complexes shift the TLR-induced cytokine production of distinct polarized human macrophage subsets towards IL-10. PLoS One (2012) 7:e35994. doi:10.1371/journal.pone.0035994

24. Kawai T, Akira S. Toll-like receptors and their crosstalk with other innate receptors in infection and immunity. Immunity (2011) 34:637-50. doi:10.1016/j. immuni.2011.05.006

25. Nish S, Medzhitov R. Host defense pathways: role of redundancy and compensation in infectious disease phenotypes. Immunity (2011) 34:629-36. doi:10. 1016/j.immuni.2011.05.009

26. Robinson MJ, Sancho D, Slack EC, LeibundGut-Landmann S, Reis e Sousa C. Myeloid C-type lectins in innate immunity. Nat Immunol (2006) 7:1258-65. doi:10.1038/nil417

27. Durandy A, Kracker S, Fischer A. Primary antibody deficiencies. Nat Rev Immunol (2013) 13:519-33. doi:10.1038/nri3466

28. Shah P, Fatehchand K, Patel H, Fang H, Justiniano SE, Mo X, et al. Toll-like receptor 2 ligands regulate monocyte Fcgamma receptor expression and function. J Biol Chem (2013) 288:12345-52. doi:10.1074/jbc.M113.449983

29. Radstake TR, van Lent PL, Pesman GJ, Blom AB, Sweep FG, Ronnelid J, et al. High production of proinflammatory and Thl cytokines by dendritic cells from patients with rheumatoid arthritis, and down regulation upon FcgammaR triggering. Ann Rheum Dis (2004) 63:696-702. doi:10.1136/ard.2003.010033

30. Ji JD, Tassiulas I, Park-Min KH, Aydin A, Mecklenbrauker I, Tarakhovsky $\mathrm{A}$, et al. Inhibition of interleukin 10 signaling after $\mathrm{Fc}$ receptor ligation and during rheumatoid arthritis. J Exp Med (2003) 197:1573-83. doi:10.1084/jem. 20021820

31. Bruhns P, Iannascoli B, England P, Mancardi DA, Fernandez N, Jorieux S, et al. Specificity and affinity of human Fcgamma receptors and their polymorphic variants for human IgG subclasses. Blood (2009) 113:3716-25. doi:10.1182/ blood-2008-09-179754

32. van Sorge NM, van der Pol WL, van de Winkel JG. FcgammaR polymorphisms: implications for function, disease susceptibility and immunotherapy. Tissue Antigens (2003) 61:189-202. doi:10.1034/j.1399-0039.2003.00037.x

33. Hepburn AL, Mason JC, Wang S, Shepherd CJ, Florey O, Haskard DO, et al. Both Fcgamma and complement receptors mediate transfer of immune complexes from erythrocytes to human macrophages under physiological flow conditions in vitro. Clin Exp Immunol (2006) 146:133-45. doi:10.1111/j.1365-2249.2006. 03174.x

34. Allhorn M, Olin AI, Nimmerjahn F, Collin M. Human IgG/Fc gamma R interactions are modulated by streptococcal IgG glycan hydrolysis. PLoS One (2008) 3:e1413. doi:10.1371/journal.pone.0001413

35. Stemerding AM, Kohl J, Pandey MK, Kuipers A, Leusen JH, Boross P, et al. Staphylococcus aureus formyl peptide receptor-like 1 inhibitor (FLIPr) and its homologue FLIPr-like are potent FcgammaR antagonists that inhibit IgG-mediated effector functions. J Immunol (2013) 191:353-62. doi:10.4049/ jimmunol.1203243 
36. Du Clos TW, Mold C. The role of C-reactive protein in the resolution of bacterial infection. Curr Opin Infect Dis (2001) 14:289-93. doi:10.1097/00001432200106000-00007

37. Mold C, Du Clos TW. C-reactive protein increases cytokine responses to Streptococcus pneumoniae through interactions with $\mathrm{Fc}$ gamma receptors. J Immunol (2006) 176:7598-604. doi:10.4049/jimmunol.176.12.7598

38. Wellington M, Dolan K, Haidaris CG. Monocyte responses to Candida albicans are enhanced by antibody in cooperation with antibody-independent pathogen recognition. FEMS Immunol Med Microbiol (2007) 51:70-83. doi:10.1111/j. 1574-695X.2007.00278.x

39. Boonnak K, Dambach KM, Donofrio GC, Tassaneetrithep B, Marovich MA. Cell type specificity and host genetic polymorphisms influence antibodydependent enhancement of dengue virus infection. J Virol (2011) 85:1671-83. doi:10.1128/JVI.00220-10

40. Chareonsirisuthigul T, Kalayanarooj S, Ubol S. Dengue virus (DENV) antibody-dependent enhancement of infection upregulates the production of anti-inflammatory cytokines, but suppresses anti-DENV free radical and pro-inflammatory cytokine production, in THP-1 cells. J Gen Virol (2007) 88:365-75. doi:10.1099/vir.0.82537-0

41. Modhiran N, Kalayanarooj S, Ubol S. Subversion of innate defenses by the interplay between DENV and pre-existing enhancing antibodies: TLRs signaling collapse. PLoS Negl Trop Dis (2010) 4:e924. doi:10.1371/journal.pntd.0000924

42. Ubol S, Phuklia W, Kalayanarooj S, Modhiran N. Mechanisms of immune evasion induced by a complex of dengue virus and preexisting enhancing antibodies. J Infect Dis (2010) 201:923-35. doi:10.1086/651018

43. Ivashkiv LB, Donlin LT. Regulation of type I interferon responses. Nat Rev Immunol (2014) 14:36-49. doi:10.1038/nri3581

44. Posch W, Cardinaud S, Hamimi C, Fletcher A, Muhlbacher A, Loacker K, et al. Antibodies attenuate the capacity of dendritic cells to stimulate HIVspecific cytotoxic T lymphocytes. J Allergy Clin Immunol (2012) 130:1368-74. doi:10.1016/j.jaci.2012.08.025

45. Zhou J, Ludlow LE, Hasang W, Rogerson SJ, Jaworowski A. Opsonization of malaria-infected erythrocytes activates the inflammasome and enhances inflammatory cytokine secretion by human macrophages. Malar J (2012) 11:343. doi:10.1186/1475-2875-11-343

46. Randall LM, Engwerda CR. TNF family members and malaria: old observations, new insights and future directions. Exp Parasitol (2010) 126:326-31. doi:10.1016/j.exppara.2010.04.016

47. Klareskog L, Ronnelid J, Lundberg K, Padyukov L, Alfredsson L. Immunity to citrullinated proteins in rheumatoid arthritis. Annu Rev Immunol (2008) 26:651-75. doi:10.1146/annurev.immunol.26.021607.090244

48. Tsokos GC. Systemic lupus erythematosus. N Engl J Med (2011) 365:2110-21. doi:10.1056/NEJMra1100359

49. El Bannoudi H, Ioan-Facsinay A, Toes RE. Bridging autoantibodies and arthritis: the role of Fc receptors. Curr Top Microbiol Immunol (2014) 382:303-19. doi:10.1007/978-3-319-07911-0_14

50. Choy E. Understanding the dynamics: pathways involved in the pathogenesis of rheumatoid arthritis. Rheumatology (Oxford) (2012) 51(Suppl 5):v3-11. doi:10.1093/rheumatology/kes113

51. Kokkonen H, Mullazehi M, Berglin E, Hallmans G, Wadell G, Ronnelid J, et al. Antibodies of IgG, IgA and IgM isotypes against cyclic citrullinated peptide precede the development of rheumatoid arthritis. Arthritis Res Ther (2011) 13:R13. doi:10.1186/ar3237

52. Quirke AM, Fisher BA, Kinloch AJ, Venables PJ. Citrullination of autoantigens: upstream of TNFalpha in the pathogenesis of rheumatoid arthritis. FEBS Lett (2011) 585:3681-8. doi:10.1016/j.febslet.2011.06.006

53. Tan Sardjono C, Mottram PL, van de Velde NC, Powell MS, Power D, Slocombe RF, et al. Development of spontaneous multisystem autoimmune disease and hypersensitivity to antibody-induced inflammation in Fcgamma receptor IIatransgenic mice. Arthritis Rheum (2005) 52:3220-9. doi:10.1002/art.21344

54. van de Velde NC, Mottram PL, Powell MS, Lim B, Holmdahl R, Hogarth PM. Transgenic mice expressing human FcgammaRIIa have enhanced sensitivity to induced autoimmune arthritis as well as elevated Th17 cells. Immunol Lett (2010) 130:82-8. doi:10.1016/j.imlet.2009.12.005

55. Mathsson L, Lampa J, Mullazehi M, Ronnelid J. Immune complexes from rheumatoid arthritis synovial fluid induce FcgammaRIIa dependent and rheumatoid factor correlated production of tumour necrosis factor-alpha by peripheral blood mononuclear cells. Arthritis Res Ther (2006) 8:R64. doi:10. 1186/ar1926
56. Mullazehi M, Mathsson L, Lampa J, Ronnelid J. Surface-bound anti-type II collagen-containing immune complexes induce production of tumor necrosis factor alpha, interleukin-1beta, and interleukin- 8 from peripheral blood monocytes via Fc gamma receptor IIA: a potential pathophysiologic mechanism for humoral anti-type II collagen immunity in arthritis. Arthritis Rheum (2006) 54:1759-71. doi:10.1002/art.21892

57. Magnusson SE, Wennerberg E, Matt P, Lindqvist U, Kleinau S. Dysregulated Fc receptor function in active rheumatoid arthritis. Immunol Lett (2014) 162:200-6. doi:10.1016/j.imlet.2014.08.016

58. Goh FG, Midwood KS. Intrinsic danger: activation of toll-like receptors in rheumatoid arthritis. Rheumatology (Oxford) (2012) 51:7-23. doi:10.1093/ rheumatology/ker257

59. Clavel C, Nogueira L, Laurent L, Iobagiu C, Vincent C, Sebbag M, et al. Induction of macrophage secretion of tumor necrosis factor alpha through Fcgamma receptor IIa engagement by rheumatoid arthritis-specific autoantibodies to citrullinated proteins complexed with fibrinogen. Arthritis Rheum (2008) 58:678-88. doi:10.1002/art.23284

60. Laurent L, Clavel C, Lemaire O, Anquetil F, Cornillet M, Zabraniecki L, et al. Fcgamma receptor profile of monocytes and macrophages from rheumatoid arthritis patients and their response to immune complexes formed with autoantibodies to citrullinated proteins. Ann Rheum Dis (2011) 70:1052-9. doi:10.1136/ard.2010.142091

61. Sokolove J, Zhao X, Chandra PE, Robinson WH. Immune complexes containing citrullinated fibrinogen costimulate macrophages via toll-like receptor 4 and Fcgamma receptor. Arthritis Rheum (2011) 63:53-62. doi:10.1002/art.30081

62. Suurmond J, Rivellese F, Dorjee AL, Bakker AM, Rombouts YJ, Rispens T, et al. Toll-like receptor triggering augments activation of human mast cells by anti-citrullinated protein antibodies. Ann Rheum Dis (2014). doi:10.1136/ annrheumdis-2014-205562

63. Sica A, Mantovani A. Macrophage plasticity and polarization: in vivo veritas. J Clin Invest (2012) 122:787-95. doi:10.1172/JCI59643

64. Wijngaarden S, van Roon JA, Bijlsma JW, van de Winkel JG, Lafeber FP. Fcgamma receptor expression levels on monocytes are elevated in rheumatoid arthritis patients with high erythrocyte sedimentation rate who do not use anti-rheumatic drugs. Rheumatology (Oxford) (2003) 42:681-8. doi:10.1093/ rheumatology/keg174

65. Hepburn AL, Mason JC, Davies KA. Expression of Fcgamma and complement receptors on peripheral blood monocytes in systemic lupus erythematosus and rheumatoid arthritis. Rheumatology (Oxford) (2004) 43:547-54. doi:10.1093/rheumatology/keh112

66. Wenink MH, Santegoets KC, Roelofs MF, Huijbens R, Koenen HJ, van Beek R, et al. The inhibitory Fc gamma IIb receptor dampens TLR4-mediated immune responses and is selectively up-regulated on dendritic cells from rheumatoid arthritis patients with quiescent disease. J Immunol (2009) 183:4509-20. doi:10.4049/jimmunol.0900153

67. Torsteinsdottir I, Arvidson NG, Hallgren R, Hakansson L. Monocyte activation in rheumatoid arthritis (RA): increased integrin, Fc gamma and complement receptor expression and the effect of glucocorticoids. Clin Exp Immunol (1999) 115:554-60. doi:10.1046/j.1365-2249.1999.00817.x

68. Wijngaarden S, van de Winkel JG, Jacobs KM, Bijlsma JW, Lafeber FP, van Roon JA. A shift in the balance of inhibitory and activating Fcgamma receptors on monocytes toward the inhibitory Fcgamma receptor IIb is associated with prevention of monocyte activation in rheumatoid arthritis. Arthritis Rheum (2004) 50:3878-87. doi:10.1002/art.20672

69. Kim WU, Sreih A, Bucala R. Toll-like receptors in systemic lupus erythematosus; prospects for therapeutic intervention. Autoimmun Rev (2009) 8:204-8. doi:10.1016/j.autrev.2008.07.046

70. Karassa FB, Trikalinos TA, Ioannidis JP. Role of the Fcgamma receptor IIa polymorphism in susceptibility to systemic lupus erythematosus and lupus nephritis: a meta-analysis. Arthritis Rheum (2002) 46:1563-71. doi:10.1002/art.10306

71. Means TK, Latz E, Hayashi F, Murali MR, Golenbock DT, Luster AD. Human lupus autoantibody-DNA complexes activate DCs through cooperation of CD32 and TLR9. J Clin Invest (2005) 115:407-17. doi:10.1172/JCI23025

72. Tel J, Beenhakker N, Koopman G, Hart B, Mudde GC, de Vries IJ. Targeted delivery of CpG ODN to CD32 on human and monkey plasmacytoid dendritic cells augments IFNalpha secretion. Immunobiology (2012) 217:1017-24. doi:10.1016/j.imbio.2012.01.016

73. Mehra S, Walker J, Patterson K, Fritzler MJ. Autoantibodies in systemic sclerosis. Autoimmun Rev (2013) 12:340-54. doi:10.1016/j.autrev.2012.05.011 
74. Ciechomska M, Cant R, Finnigan J, van Laar JM, O’Reilly S. Role of toll-like receptors in systemic sclerosis. Expert Rev Mol Med (2013) 15:e9. doi:10.1017/ erm.2013.10

75. Kim D, Peck A, Santer D, Patole P, Schwartz SM, Molitor JA, et al. Induction of interferon-alpha by scleroderma sera containing autoantibodies to topoisomerase I: association of higher interferon-alpha activity with lung fibrosis. Arthritis Rheum (2008) 58:2163-73. doi:10.1002/art.23486

76. Tan FK, Zhou X, Mayes MD, Gourh P, Guo X, Marcum C, et al. Signatures of differentially regulated interferon gene expression and vasculotrophism in the peripheral blood cells of systemic sclerosis patients. Rheumatology (Oxford) (2006) 45:694-702. doi:10.1093/rheumatology/kei244

77. Mavragani CP, Tzioufas AG, Moutsopoulos HM. Sjogren's syndrome: autoantibodies to cellular antigens. Clinical and molecular aspects. Int Arch Allergy Immunol (2000) 123:46-57. doi:10.1159/000024423

78. Pan M, Liu X, Zheng J. The pathogenic role of autoantibodies in pemphigus vulgaris. Clin Exp Dermatol (2011) 36:703-7. doi:10.1111/j.1365-2230.2011. 04092.x

79. Weber MS, Hemmer B, Cepok S. The role of antibodies in multiple sclerosis. Biochim Biophys Acta (2011) 1812:239-45. doi:10.1016/j.bbadis.2010.06.009

80. Melief J, Koning N, Schuurman KG, Van De Garde MD, Smolders J, Hoek RM, et al. Phenotyping primary human microglia: tight regulation of LPS responsiveness. Glia (2012) 60:1506-17. doi:10.1002/glia.22370

81. Gelfand EW. Intravenous immune globulin in autoimmune and inflammatory diseases. N Engl J Med (2012) 367:2015-25. doi:10.1056/NEJMra1009433

82. Schwab I, Nimmerjahn F. Intravenous immunoglobulin therapy: how does IgG modulate the immune system? Nat Rev Immunol (2013) 13:176-89. doi:10.1038/nri3401

83. Bouhlal H, Martinvalet D, Teillaud JL, Fridman C, Kazatchkine MD, Bayry J, et al. Natural autoantibodies to Fcgamma receptors in intravenous immunoglobulins. J Clin Immunol (2014) 34(Suppl 1):S4-11. doi:10.1007/ s10875-014-0019-2

84. Chu SY, Vostiar I, Karki S, Moore GL, Lazar GA, Pong E, et al. Inhibition of B cell receptor-mediated activation of primary human B cells by coengagement of CD19 and FcgammaRIIb with Fc-engineered antibodies. Mol Immunol (2008) 45:3926-33. doi:10.1016/j.molimm.2008.06.027

85. Horton HM, Chu SY, Ortiz EC, Pong E, Cemerski S, Leung IW, et al. Antibodymediated coengagement of FcgammaRIIb and B cell receptor complex suppresses humoral immunity in systemic lupus erythematosus. J Immunol (2011) 186:4223-33. doi:10.4049/jimmunol.1003412

86. Chu SY, Yeter K, Kotha R, Pong E, Miranda Y, Phung S, et al. Suppression of rheumatoid arthritis B cells by XmAb5871, an anti-CD19 antibody that coengages B cell antigen receptor complex and Fcgamma receptor IIb inhibitory receptor. Arthritis Rheumatol (2014) 66:1153-64. doi:10.1002/art.38334

87. Szili D, Cserhalmi M, Banko Z, Nagy G, Szymkowski DE, Sarmay G. Suppression of innate and adaptive $B$ cell activation pathways by antibody coengagement of FcgammaRIIb and CD19. MAbs (2014) 6:991-9. doi:10.4161/ mabs. 28841

88. Weinblatt ME, Kavanaugh A, Genovese MC, Musser TK, Grossbard EB, Magilavy DB. An oral spleen tyrosine kinase (Syk) inhibitor for rheumatoid arthritis. N Engl J Med (2010) 363:1303-12. doi:10.1056/NEJMoa1000500
89. Benoit M, Desnues B, Mege JL. Macrophage polarization in bacterial infections. J Immunol (2008) 181:3733-9. doi:10.4049/jimmunol.181.6.3733

90. Heusinkveld M, van der Burg SH. Identification and manipulation of tumor associated macrophages in human cancers. J Transl Med (2011) 9:216. doi:10. 1186/1479-5876-9-216

91. Scott AM, Wolchok JD, Old LJ. Antibody therapy of cancer. Nat Rev Cancer (2012) 12:278-87. doi:10.1038/nrc3236

92. Suurmond J, Stoop JN, Rivellese F, Bakker AM, Huizinga TW, Toes RE. Activation of human basophils by combined toll-like receptor- and FcepsilonRItriggering can promote Th2 skewing of naive T helper cells. Eur J Immunol (2014) 44:386-96. doi:10.1002/eji.201343617

93. Janczy JR, Ciraci C, Haasken S, Iwakura Y, Olivier AK, Cassel SL, et al. Immune complexes inhibit IL-1 secretion and inflammasome activation. J Immunol (2014) 193:5190-8. doi:10.4049/jimmunol.1400628

94. Sutterwala FS, Noel GJ, Salgame P, Mosser DM. Reversal of proinflammatory responses by ligating the macrophage Fcgamma receptor type I. J Exp Med (1998) 188:217-22. doi:10.1084/jem.188.1.217

95. Gerber JS, Mosser DM. Reversing lipopolysaccharide toxicity by ligating the macrophage Fc gamma receptors. J Immunol (2001) 166:6861-8. doi:10.4049/ jimmunol.166.11.6861

96. Bandukwala HS, Clay BS, Tong J, Mody PD, Cannon JL, Shilling RA, et al. Signaling through $\mathrm{Fc}$ gamma RIII is required for optimal $\mathrm{T}$ helper type (Th) 2 responses and Th2-mediated airway inflammation. J Exp Med (2007) 204:1875-89. doi:10.1084/jem.20061134

97. Zhang Y, Liu S, Liu J, Zhang T, Shen Q, Yu Y, et al. Immune complex/Ig negatively regulate TLR4-triggered inflammatory response in macrophages through Fc gamma RIIb-dependent PGE2 production. J Immunol (2009) 182:554-62. doi:10.4049/jimmunol.182.1.554

98. Gallo P, Goncalves R, Mosser DM. The influence of IgG density and macrophage Fc (gamma) receptor cross-linking on phagocytosis and IL-10 production. Immunol Lett (2010) 133:70-7. doi:10.1016/j.imlet.2010.07.004

Conflict of Interest Statement: The authors declare that the research was conducted in the absence of any commercial or financial relationships that could be construed as a potential conflict of interest.

Received: 06 January 2015; accepted: 10 February 2015; published online: 24 February 2015.

Citation: Vogelpoel LTC, Baeten DLP, de Jong EC and den Dunnen J (2015) Control of cytokine production by human Fc gamma receptors: implications for pathogen defense and autoimmunity. Front. Immunol. 6:79. doi: 10.3389/fimmu.2015.00079

This article was submitted to Inflammation, a section of the journal Frontiers in Immunology.

Copyright (C) 2015 Vogelpoel, Baeten, de Jong and den Dunnen. This is an open-access article distributed under the terms of the Creative Commons Attribution License (CC $B Y)$. The use, distribution or reproduction in other forums is permitted, provided the original author(s) or licensor are credited and that the original publication in this journal is cited, in accordance with accepted academic practice. No use, distribution or reproduction is permitted which does not comply with these terms. 